\title{
Educational Innovation: Reading Meaning and Sense
}

\author{
Evelyne Suárez Hortiales, Angelica Ramos Nieto*, María Elena Zepeda Hurtado \\ Center for Science and Technology Studies no. 15, "DAE" Instituto Politécnico Nacional, Cd. Mx. Mexico
}

Copyright $\subset 2017$ by authors, all rights reserved. Authors agree that this article remains permanently open access under the terms of the Creative Commons Attribution License 4.0 International License

\begin{abstract}
In recent years concern about Mexican reading habits has increased. Statistics show short reading interest; an average Mexican reads 3.8 books a year [1]. As teachers, reading habits are important and reflect students' skills and academic performances. Many teachers would complain about students reading habits; it is considered to be non-existent. Teachers might say "students neither read nor write." Students lend and borrow books; questions rely on what are students reading? How do students understand what they know? A survey was carried out on a random sample of students from "Centro de Estudios Científicos y Tecnológicos" (CECyT) campus 11 "Wilfrido Massieu" and campus 15 "Diódoro Antúnez Echegaray" belonging to Instituto Politécnico Nacional (IPN), to know readings and motivations. Quantitative methodologies with an exploratory range were applied. Results; students mostly read books from which North American movies based on, best and long seller books and pdf formats. A workshop was brought about, four sessions per month, to discuss each book, themes, and students' perceptions. Monitors were teachers from different areas and school subjects. Teacher's prejudices interfered on student's discussions and opinions. Reading is a complicated process; it is developed from previous stages. Resume doing, as the primary objective, impedes students from comprehending all information.
\end{abstract}

Keywords Reading Habits, Reading Index, Best Seller, Extensive Reading

\section{Introduction}

For years Mexico has been considered to be a distant reading country, and for more than a hundred years more than $82 \%$ of the society was illiterate, today this number has decreased to $6.9 \%$. According to UNESCO, from 108 countries base, Mexico takes the next to last place for reading habits. The average Mexican reads less than three books a year, three hours or less a week. And only four of each ten people are used to read. Nowadays $60 \%$ of young people have received a reading education in contrast to adults of 56 years and more who did not. $48 \%$ of young people have never been in a library, but just $12 \%$ reads regularly. [2]
Recently, the "Primera Encuesta Nacional Sobre Consumo Digital y Lectura", ("First National Survey on Consumption of Digital Media and Reading), carried out by IBBY México/A leer, is stated that teenagers do read, $76 \%$ said that they enjoy electronic and printed formats, which contrasts to other assertions. The interview also highlights the fact that most contents are news and brief text such as articles, reviews, tutorials and tips, which are read mainly in digital format. On the contrary, when reading literature and novels, printed books are favorite. Then it is clear from observation that students at CECyT 11 and 15, do read, so the hypothesis says if students understand it is convenient to know what they are reading and how they are reading it.

The present work deals with reading problems in Mexico, particularly focused on two high schools, from Instituto Politécnico Nacional: Centro de Estudios Científicos y Tecnológicos (CECyT 11) $\mathrm{N}^{\circ} 11$ "Wilfrido Massieu" and CECyT 15 "Diódoro Antúnez Echegaray." Some teachers from those schools would claim, during teachers sessions, that "students neither read nor write" such assertion was made in response to the questioning of students failing, exams, practices, and terms in general, and becoming a way to justify low grades. As an answer to such assertions, the following investigation was carried out.

\section{Subjects and Methods}

\section{Subjects}

IPN, high school division, comprehends students from 15 to 18 years old mainly. CECYT 11 "Wilfrido Massieu" (WM) located in Mexico City in the area of Gustavo A. Madero section and CECyT 15 "Diódoro Antúnez Echegaray" (DAE) in Milpa Alta section. Students from both schools live in Mexico City and outskirt as well as some Mexico State townships. These high schools belong to the area of Engineering and Physical-Mathematical Sciences (SPM) and Medical-Biological Sciences (MBS), respectively.

\section{Methods}

To know what the students of high school read, a survey was designed by the Language and Communication 
Academy of both high schools. The information obtained from the study was compiled and analyzed by the statistical program SPSS.

\section{Procedure}

100 students were surveyed between the corridors to encourage students' participation. Generating no mistrust surveys were applied by students who performed their social service within the research project and from the same school.

After the interview and obtaining results from the analysis, reading workshops at CECyT 15 and CECyT 11 were organized, spread and advertised through both school communities. Teachers from the same schools and different areas were invited to participate in the workshops with a book. It is an hour session per week. Each text discussion took a month. It is an hour session per week. The teacher might introduce topics, but students decided if it was relevant to discuss, following each book chronology. Observations were reported and reviewed during further teachers' sessions.

\section{Results}

If these titles were 100 percent, the results show: what books have you read? 166 different titles were mentioned, many of which were repeated. Books referred to only one person were dismissed, 109 in the final count.

Table 1. Titles mentioned by students, number of times mentioned. 106 titles in total

\begin{tabular}{|l|c|}
\hline \multicolumn{1}{|c|}{ Book and author } & $\begin{array}{c}\text { \# of times } \\
\text { repeated }\end{array}$ \\
\hline Harry Potter. Rowling, J. K. & 9 \\
The hunger games. Collins. S. & 9 \\
Las batallas en el desierto. Pacheco, J. E. & 6 \\
The little prince. Saint-Exupery, A. & 7 \\
El retrato de Dorian Gray. Wilde, O. & 5 \\
El alquimista. Coelho, P. & 4 \\
Cien años de soledad. García Márquez, G. & 4 \\
Crepúsculo (Saga integrada por 4 libros). Meyer, S. & 4 \\
Divergente (Saga integrada por 3 libros). Roth, V. & 4 \\
El perfume. Suskind, P. & 4 \\
La Iliada. Homer & 4 \\
The Odyssey. Homer & 3 \\
La mecánica del corazón. Malzieu, M. & 4 \\
La alargada sombra del amor. Malzieu, M. & 6 \\
Diario de Ana Frank & 3 \\
El caballero de la armadura oxidada. Fisher, R. & 3 \\
Hush, Hush. (Saga integrada por 3 libros). Fitzpatrick, B & 3 \\
La metamorfosis. Kafka, F. & 3 \\
Los ojos de mi princesa. Sánchez, C. C. & 3 \\
Speak. Anderson, L. H. & 3 \\
Flowers in the attic. Andrews, V. & 3 \\
The perks of being a wallflower. Chbosky, S. & 3 \\
Lord of the Flies. Golding & 3 \\
Fifty shades of Grey. James, E. L. & 3 \\
The analyst, Katzenbach, J. & 3 \\
Quiéreme cinco minutos. López, A. & 3 \\
\hline
\end{tabular}

Students answered freely; therefore titles like Harry Potter appeared. Besides, each reader placed in brackets the word, saga, meaning seven books, to The Picture of Dorian Gray by Oscar Wilde, or The Odyssey by Homer. Among the titles, which have been read by interviewed students, most men and women have read Harry Potter (complete saga); the games of hunger (saga); The Little Prince; The battles in the desert and The Picture of Dorian Gray.

To the question: What book would you read in the classroom? 75 students answered, and 25 did not. 47 different titles were recommended. Standing out four texts to discuss within the classrooms: The battles in the desert by J.E. Pacheco, The Hunger Games by S. Collins, Fifty Shades of Grey by E. L. James, The analyst, Katzenbach, J. As result, it is possible to observe that a greater number of students prefer to read bestseller titles.

If these four titles were 100 percent, then students read for pleasure $75 \%$ of books. The remaining titles have a single reader for each of the suggestions.

During a further reunion with social service students, the following books were agreed to reading during subsequent "Reading Workshop" sessions in the next order, and teachers proposed only the Lord of the lies and The Little Prince were accepted by students. As shown in the following table.

Table 2. Relation of reading workshop books and subject teachers

\begin{tabular}{|l|l|}
\hline Read Titles Order & Teacher's subject \\
\hline 1. Fifty shades of Grey & English \\
\hline 2. Lord of the flies & Maths \\
\hline 3. Quiéreme 5 minutos (Love me 5 minutes) & History \\
\hline 4. The perks of being a wallflower & Maths \\
\hline 5. The Analyst & Psychology \\
\hline 6. Flowers in the attic & IT \\
\hline 7. The little prince & $\begin{array}{l}\text { English \& } \\
\text { Psychology }\end{array}$ \\
\hline 8. Speak & History \\
\hline
\end{tabular}

Seven teachers from different subjects and different backgrounds monitored a, book; only one teacher conducted two books workshop.

Attendance to sessions was variable, since workshops were an after class activity, during assessment periods attendance decreased. The book sessions which registered a higher attendance were Fifty Shades of Grey, Lord of the Flies and The little prince.

\section{Discussion}

Index reading and academic performance are related to the economy (poverty), hunger (students do not eat before school), insecurity, the family (single parent home); School role has changed (students prefer to stay longer than arriving home to be alone). With these social symptoms, after the PISA evaluation, it is clear that Mexico is a country of 
nonreaders. Furthermore, writers such as Elena Poniatowska have confirmed this: "Mexico is not a country of readers,..." [3]. It is hard to accept that teachers do believe such assertion, who not only reinforce the idea, yet the few texts at students scope are unknown (by them) furthermore are used to label them. Some teachers do not consider those books as reading. These actions discourage the few readers, who do not have in their hand's literary works of the stature of the Nobel prizes. This is not because they do not want it, but because they have no one who can guide them. To top it all, in a country of nonreaders; teachers are not interested in reading books students do, "best seller" books.

When asked the question, what motivates you to read? If one considers the objectives of reading proposed by Solé, read to obtain accurate information, to follow instructions, to get general information, to learn, to review your writing for pleasure, to communicate a text to an audience, to practice reading aloud, or to measure what you have learned. [4] Then students become the objective, they should guide the selection of each teacher and class texts. In general, regardless the goals of the National Reading Program [5], the product will be a summary, which becomes the same boring task. In other words, students' reading practice outside the school should be accepted, discussed and encouraged. The disqualification or rejection of student's books is what propitiates that the abyss between books called best sellers and literary ones, concluding that formative books turn out to be boring to students. Likewise, each reading objective should be accompanied by a different product, but teachers seem to find no time to, first establish the purpose and then design a product, meaning that what the student will do with the reading becomes the same result a summary of "principal ideas."

Every interviewed student mentioned that the product from each reading was a summary, as the single answer. Making evident, no matter if they did it or not, the task makes. From such statement, another question arises: why do they read what they read? And this issue generates the following, why teachers do not know what the students read? It is important to highlight that, the type of reading, which young people read, is a reflection of culture, youth, and inexperience. School pretends to form reading habits without knowing the student's' academic backgrounds, tastes and other factors that influence readers: the way their curiosity has been encouraged or crushed.

A book for entertaining will always be more attractive than a formative one. The communicative character attributable to "best seller books," relies on the unusual, exciting, mystery and even morbid, while the literature ones will have greater difficulty reaching the adolescent because, for most adolescents, it implies rejection, as is associated with school grades, difficulty and the in the lack of context. For the first one, reading skills are not necessary, because it does not require understanding. It becomes a way to "kill time," and non-related to school; while the second, claims to appropriate the language, to be hidden to avoid the rude comments from others and self-commitment. There are no considerations when saying "read twenty minutes," says "El Zarco," (in the context of a Mexican reading campaign). The very fact of saying "I let you read..." "Have you read..? For the first expression, there would be no problem with what students read. Enthusiastic young people can abandon everything: food, sleep, fatigue, among others, just to finish their reading.

Considered quality reading (literature texts by recognized Nobel prizes) which teachers assigned, like the Zarco or The Quixote, are decontextualized. As a result, students reject them. Because they do not know the literary value, narrative technique, historical, the social context in which they were written and the reflections of their time. What to do in this case?

Students do read and do it without obligation; they recommended each other, and then the books are lent and borrowed.

A remarkable discovery was that two blocks had been formed. Without even being aware of it, students who started reading literary books (Gabriel García Márquez, Jorge Luis Borges, among others), become those who continue reading a literary text. While those who started reading bestseller books keep on reading the same kind of books, and each block claims the other's choices are boring.

How to change the reading perception? Reading for pleasure involves sharing, talking about content. Since students exchange their points of view about the themes they perceived in each of the books: friendship, unconditional love of one mother, love, political control, coexistence. Needless to say, all topics have been proposed by students. The teacher should be willing to work with this type of reading, should learn to make a trade: bestseller and literary work. But most important is that dynamics must change for literary books because while success books are read by student voluntarily, reading literature books can be perceived as an obligation.

To motivate the reading of literary works, in addition to the accompaniment, reading aloud and question the listeners in the classroom must be practiced, drive readers: What would you do if? How could you lead with this? This type of question should be generated long before the book is submitted to the students' judgments, to know when to stop and exchange information about characters' life circumstances, the problems reflect the actors or the social issues that the author is reflecting on his/her work.

It is also necessary to contextualize each of the literary works. Otherwise, it will only generate a superficial reading. For example, the book of Aura, by Carlos Fuentes, was banned in Mexico [6], as a text to be read and commented at school because an adult was offended by the content. Regardless of their opinion, it is hard to process all the information because the reading was left free and the interpretation was not questioned or commented. So students had a vague idea due to the product: a summary. These actions discourage students' reading intentions. Each reader 
requires a response; needless to say, summarizing isolates the students' concerns. Not solving learners' doubts. If such behavior continues then, Mexico will continue to have the same qualifications in the PISA evaluation and will continue to generate programs to make us believe that something is being done to promote reading habits. We can continue to measure reading by time, but it will never reflect quality.

What should be done to motivate teens to read? First, a texts selection: the authors; second, the amount to read; third, the place. The significant advantage offered by the writers of "quality" is that they write stories. Teachers could start by introducing some short stories, and tales, one or two stories by writers such as Gabriel García Márquez, Juan Rulfo, Jorge Luis Borges or Julio Cortázar, among others. The best place to read is at school, in the classroom, during the session. The dynamic might be given forth by the same group but will depend on the type of questions previously designed. It based on the target to be achieved with the text itself.

During reading sessions, it was possible to observe teachers' fears and prejudices at facing adolescents' problems. Repeatedly interferes with the content. Some teachers would omit or pretended to overlook when talking about sexual abuse. They might say that the book was referring to something "like just, inappropriate grabbing," as reading in the book of Speak and The Perks of Being a Wallflower when the main character faced sexual abuse, and Flowers in the attic while talking about incest. The teacher in charge would skip the chapter. Then it is clear that teachers might be not prepared to face those topics since students would talk about their own experiences and we as teachers may feel useless towards students' issues. When talking about sexuality, some teachers might avoid the fact that the books referred to it. Teachers who avoided talking about these human conditions belong to technological areas. It is clear that previous formation is relevant when talking about adolescents, emotions, and perceptions. It was also noticeable that their male condition also interferes.

What is the meaning of reading? For a teacher, to let the student read and value the content of the text goes beyond mere entertainment. For students, reading is something completely different. Young people read to have fun, to kill time and they said they like reading meaningful books. From this perspective, the challenge may seem impossible to achieve; However, and alluding to the past of students, how did they learn to value literary works? Reading inside the classroom and outside, has to do with questions to answer. The contextualization of the teacher and the presentation of each topic, taking the book on hands and quoting passages to be discussed, make reading more attractive.

With this background, the work is not impossible. It only takes time. A school syllabus can be approached through the text, making it relevant for the student's life. Teaching to read also implies learning to value. In front of a teenager who does not read, the teacher can show students the way, and it will be through reading out loud. Then the classroom offers the possibility to open spaces for the imagination and awaken literary curiosity. There must be a careful selection of literary texts, texts which make sense into students' minds, for all initiation takes time. It should not be abandoned or drifted, and teachers' guidance is essential. For example, for reading have special meaning at high school stage, texts related to adolescents' life, their problems, and their interests should be considered. Stories such as Milan Kundera's Unbearable Lightness of Being and On Sunday by Mario Vargas Llosa open the possibility of providing experiences to students. Reading out loud alluded questions and the comments of students. Reading makes sense and acquires meaning when related not only to the content but a place. The literary movement or generation to which the author belongs motivates to delve deeper into other readings of the same author or related ones; little by little, texts should be extended, from the story to the short novel, from this to the novel. Perhaps some plays by the same author or a contemporary.

Another point of utmost importance is the product, to be congruent with language skills: speaking, listening, reading and writing. Activities should respect this dynamic, such as reading aloud involves listening; questioning motivates to talk about the reading, in the case of literary texts a commentary or review, or even an essay which can be a task to develop. Depending on the understanding you can adapt to the complexity of the product. It is suggested to work with the PNI (Positive, Negative, and Interesting) diagram, and proposed in the book Constructivism. Teachers should apply strategies to learn [7] because it facilitates the student information extraction and also ideas recognition.

When writing a review, which is already more complex. The chart; What I Know, What I Want to Learn, What I Learned [7] can be a useful tool. It is suggested to work on filling column one, before starting to read the book or the chapter. The second column is recommended to complete during the reading and, at the end or after reading the column three is filled. Any assigned reading implies a commitment from the one who suggests; it changes the way to register reading control. Writing a report about what student read can be helpful. Teachers must be open to using other resources to help student's process information, rather than a summary making.

\section{Conclusions}

Reading is an incredibly important skill within young students' academic life and in the life of every human being. However, teachers should consider that when the reader gets bored with the task. Then it is not only students' fault that he/she does not like reading. Maybe what he does not like and has not distinguished so far is what kind of readings he or she feels motivated by. In any case, what the student seems to upsets is to make a summary all the time. Teachers of any subject are responsible for stimulating or discouraging reading and are unconscious, examples of their role, as the 
saying goes "walk the talk."

In the classroom, you should take advantage of the fact that youth is anxious to know. Teachers can motivate curiosity through the texts, "read," "search," "investigate." "What you just told me looks like... ", words that refer to students readings should be less aggressive, and less derogatory. The day teachers break the paradigm of seeing the world of adolescent readers as aliens to the expert readers and talk about their own stories; then it will be possible to attract youths into the "quality" reading, which does count in the academic curriculum.

\section{REFERENCES}

[1] Alegría A. INEGI: continúa el rezago en lectura. [internet]. 2016 April 15th. La Jornada en línea http://www.jornada.com.mx/ultimas/2016/04/15/mexicanos-r ezagados-en-lectura

[2] First National Survey on Consumption of Digital Media and Reading. [Internet] 2016. November. A leer. IBBY México. http://www.ibbymexico.org.mx/

[3] México no es un país de lectores, pero podemos llegar a ser Presidente de la República: Poniatowska [Internet]. Oaxaca entrelineas.com (México). 2012 Oct: [Publisher unknown].

[4] Solé I. Estrategias de lectura. 15 a ed. Barcelona: Grao; 2004.

[5] Programa Nacional de Lectura [Internet] México: SEP. 2014 Jan [cited 2016 May 20]. Available from http://www.sep.gob.mx/es/sep1/sep1_Programa_Nacional_de _la_Lectura\#.WRmwC1U1_IU

[6] 'Aura', libro de Carlos Fuentes fue censurado por ser inapropiado [Internet] México 2017 June. 13th [cited 2017]. http://www.excelsior.com.mx/2012/05/15/nacional/834376

[7] Pimienta J. Constructivismo: estrategias para aprender a aprender. $3^{\text {a }}$ ed. Mexico: Pearson/Prentice Hall; 2008:24 